\title{
Mediating Identities: Community Arts, Media, and Collective Identity in the Frontline Resistance to Fracking
}

\author{
Paula Serafini ${ }^{1 *}$
}

\author{
${ }^{1}$ University of Leicester, 7 Salisbury Road, Leicester LE17RQ, UNITED KINGDOM
}

*Corresponding Author: paula.serafini@le.ac.uk

Citation: Serafini, P. (2018). Mediating Identities: Community Arts, Media, and Collective Identity in the Frontline Resistance to Fracking, Journal of Cultural Analysis and Social Change, 3(2), 11. https://doi.org/10.20897/jcasc/3992

Published: December 22, 2018

\begin{abstract}
Vista Alegre is a municipality in the province of Neuquén, Argentina. Situated in a region traditionally known for its fruticulture economy, Vista Alegre has recently been identified as a potential location for fracking, a development that has resulted in widespread opposition among its inhabitants. The fight against fracking in Vista Alegre has followed a number of channels, from road blockades to art festivals and a legal challenge to the municipality. This paper analyses the conflict focusing on the forms of community art and media employed by the local assembly against fracking to widen and sustain participation in the struggle, and the role that these media have in mediating collective identity processes in the fight against fracking. Building on the concept of mediated identities (Fornäs and Xinaris, 2013), I look at these community art and media practices as dialogical (Kester, 2004). I propose that activities such as art festivals, mural painting and open radios contribute to collective identity processes through three mediating tactics: participation, knowledge sharing and the event modality. I conclude by arguing that these forms of community arts and media can be seen as a productive output of the conflict (Merlinsky, 2015), as they become crucial practices of cultural resistance.
\end{abstract}

Keywords: collective identity, mediated identity, community arts, community media, fracking

\section{INTRODUCTION}

The Argentine Patagonia, the southernmost region of the country, was incorporated into the national territory in the late nineteenth century following the 'conquest of the desert', a military campaign that resulted in the killing and displacement of thousands of indigenous people. The region has for long been marked by fossil fuel extraction, but it has recently become a site of increased economic interest to national and transnational capital (Riffo, 2017). This expansion of the extractive industries has been met by the resistance of indigenous mapuche communities claiming back ancestral land and other local communities protecting their environment and traditional economies (Svampa and Viale, p. 2014). Protests against the socioenvironmental effects of fossil fuel extraction have for decades taken place in the region (GER-GEMSAL, 2013, p. 771), but it has been since the recent development of the Vaca Muerta (Dead Cow) megaproject, which brought with it the technology of fracking ${ }^{1}$ (Taller Ecologista and Observatorio Petrolero Sur in EJES, 2018), that fossil fuel extraction and its surrounding conflicts have reached a new peak in terms of intensified mobilisations, followed by state repression.

\footnotetext{
${ }^{1}$ Hydraulic fracturing or fracking is a technique employed for the extraction of non-conventional fossil fuels that has been linked to water source contamination and seismic activity. For an overview of fracking see BBC News (2015) 'What is fracking and why is it controversial?' http://www.bbc.co.uk/news/uk-14432401
} 
Focusing on the case of Vista Alegre, a community resisting fracking in their territory in the province of Neuquén, Argentina, this article seeks to interrogate the concept of mediated identities in the context of collective action at a local level. I build on scholarly work on the collective identity of movements (Melucci, 1996; Klandermans et al., 2002) and the role of art and media in community identity processes (Bang and Wajnerman, 2010; Dewey, 1985, 2005; Kester, 2004, 2011; Lowe, 2000) by applying the concept of mediated identities (Fornäs and Xinaris, 2013) at the micro level and analysing the tactics through which mediation takes place in community arts and media practices in Argentina's frontline resistance to fracking.

Following a review of the literature, I describe the conflict surrounding fracking in Vista Alegre and the narratives of opposition that have emerged as a result. I then examine the role of three types of community arts and media-festivals, murals and 'open radios' - in the reimagining and sustaining of a collective identity that reinforces place-based elements while incorporating an anti-fracking stance. Adopting a perspective that considers the importance of collective identity in collective action and the dialogical potential of creative practice, I argue that the rich arts and media programme of Vista Alegre's assembly against fracking has taken a central role in championing the transformation of the locality's collective identity as a way of strengthening collective action. Through an analysis of specific examples, I propose that there are three tactics in the production of community arts and media that are employed in order to mediate this process at a local level: participation, knowledge sharing and the event modality. As a result of this interrogation, this article makes three specific contributions. First, it advances research on the culture and identity of social movements and collective action by expanding the theorisation of collective identity mediation at the micro level. Second, it proposes an empirically-informed frame of analysis for understanding the tactics through which community arts and media can be employed in mobilising communities and facilitating collective identity processes. And third, it offers an empirical account of the growing but still under-studied conflict surrounding fracking in the Argentine Patagonia.

\section{THEORETICAL FRAMEWORK}

\section{Collective Identity in Collective Action}

Collective identity, be that in the context of community resistance or large-scale social movements, is a foundational feature of collective action (Melucci, 1996). As Fornäs and Xinaris explain,

Identity formation can be broadly described as the development of ways to define and give meaning to individuals or collectives in relation to others and to themselves. Identities are formed both from within and from the outside, in a complex interplay of mutual recognition and understanding of self and others (Fornäs and Xinaris 2013, p. 12).

Collective identity is central in activism because it 'creates a shortcut to participation' (Klandermans et al., 2002, p. 236). That is to say, that feeling part of a group or community and identifying with those involved tends to be a stronger draw than the demands and outcomes of the movement itself. Indeed, argues Melucci, 'isolated and rootless individuals never mobilize', and it is the relational networks embedded in the social fabric that 'facilitate involvement processes and make it less costly for individuals to invest in collective action' (Melucci, 1996, p. 65). Mobilisations are often started by those who already have an identity and wish to defend it. But identity is not fixed, it is 'constructed and negotiated through a recurrent process of activation of the relations that bind actors together' (Melucci, 1996, p. 70), and transforms alongside the evolution of movements (Della Porta and Diani 2007, p. 110). In collective action, collective identity processes are often facilitated by leading figures; these can be strong leaders or moderate ones-what Gerbaudo (2012) has termed 'choreographers'.

At a global scale, the environmental movement is not homogenous, and there is not one shared collective identity. However, research in the field of political ecology has noted the shared experiences of several communities at the frontlines of environmental degradation across the world, linking the environmental justice movement in the United States with the 'environmentalism of the poor' in Latin America, Africa and Asia, and suggesting the existence of a movement of global dimensions (Martinez-Alier et al., 2015, p. 732). This movement is global, even if most conflicts target local grievances, because such events belong to "classes of conflicts that appear regularly elsewhere in the world" - e.g. fracking - or because they raise the issue to a global scale through global networks (Ibid, 747). Within this, however, movements at a local scale develop their own narratives and identities. For this reason, it is useful to look at these in relation to place.

In his study of Occupy Mongkok, Yuen develops the concept of place-based collective identity. Place here is not only a physical space, but is 'conceived of as a historically, socially, and culturally constituted space', which serves to gather political actors and solidify a political force (Yuen, 2018, p. 3). When considering the role of place in identity we must also consider scale. A shift from community to movement, or from local to part of a wider, global struggle, as has been the case of Vista Alegre, can be understood within the frame of identity boundaries (Drury et al., 2003, p. 192). Boundary framing is a process, and it is the result of discussions within the collective 
which allow people to define the internal relations of that collective and the ones with external actors (Drury et al., 2003, p. 206). Indeed, focusing on the role of interpersonal interactions is crucial for understanding how the social construction of meaning occurs (Klandermans, 1992). It follows that narratives also have a central role in the building of collective identities; in the context of conflict, narratives are important tools of communication, and can also be strategic (Polletta, 1998, p. 420). Political actors 'construct narratives in order to communicate their ideas to the organisations they are protesting against, to the general public, and to themselves' (Serafini, 2018).

Collective identity processes are shaped by the forms of media that activists use in order to generate and share symbols and stories related to a movement (Gerbaudo and Treré, 2015); both form and content matter. Collective identities can therefore be understood as mediated, when mediation, according to Fornäs and Xinaris, menas 'that something functions as a linking device between different entities', and 'media are socially organised technologies made for being used in the practices of communication that are prime examples of such mediating processes.' (Fornäs and Xinaris, 2013, p. 15). The two authors also argue that 'people shape their tools of communication that then shape them.' (Fornäs and Xinaris, 2013, p. 12). In collective action art and media serve as the channels through which the narratives of a movement are communicated to those within and outside of it, but also, they are often the tools and languages through which narratives are formed and identities negotiated (Serafini, 2018), or in other words, mediated. Following this line of thought, I will now move on to an exploration of community arts and media as practices through which those interactions can take place.

\section{Arts and Media as Community Resistance}

Dewey's seminal work on art and society emphasises the importance of art as an experience, moving away from a focus on the artwork as object and towards an understanding of art as a transformative event (Dewey, 2005 [1934]). Dewey celebrates the accessibility of the popular arts, and argues that art can help develop the identity of citizens, and thus enable people to become politically active. At a community level, he adds, art can enable organising for problem solving, and foster debate over pressing issues within a community (Dewey, 1985 [1927]).

Community art can be regarded as 'a distinct setting for social interaction' (Lowe, 2000, p. 360). It is inclusive and collaborative in nature, and usually consists of artists working with non-artists in order to create work that is in the public interest (Raven, 1993; Lowe, 2000, p. 364). In the case of Vista Alegre, however, the art and media projects that emerged from the fight against fracking are initiatives of community members themselves; some of them artists and community organisers and others not. While artists and musicians from outside the neighbourhood sometimes take part in the activities, we could describe this type of community art as 'self-led', in order to distinguish it from the kind of participatory practices that bring outsider artists into an unknown setting, removing agency from the community and verging on the 'evangelical' (Shaughnessy, 2005, p. 209).

Community art provides experiences of community life and shared making that can enhance feelings of unity and belonging (Lowe, 2000, p. 366), as well as generating a sense of collective identity (Ibid, 377), working on common concerns, and developing feelings of solidarity (Ibid, p. 371). In the case of Vista Alegre, the community is already existing; what is sought by assembly organisers, as I will demonstrate, is an opportunity to widen the locus of shared identity and belonging from a shared culture and sense of place towards including also an element of joint opposition to fracking.

Looking at the Argentine context specifically and from the perspective of social psychology, Bang and Wajnerman (2010) argue that at a time where society is characterised by the weakening of relationships and the dismembering of spaces for community organisation, the generation of processes of collective art-making contributes to a community's ability to become agents of transformation in their immediate realities. One of the stages of collaborative art in community settings is the collective or 'group' process, in which a community has the opportunity to jointly deal with an issue or need. This process is not only the result of the interpersonal relationships established, but also of the participation in different decision-making processes on behalf of members, during which information is shared and common parameters and positions can be built (Bang and Wajnerman, 2010, p. 93). Bang and Wajnerman situate community art as a distinct kind of creative practice, different from 'elite' and 'commercial' art; that is, 'popular art', or art of the people. Borrowing from Ticio Escobar, they define popular art as the set of aesthetic expressions of a given culture which are able to reveal truths about that culture (Escobar, 2004, p. 153; Bang and Wajnerman, 2010, p. 95-96). Following Colombres (2004), they propose that popular art can be seen as rite (as opposed to spectacle, which would apply to other kinds of artistic events), because it facilitates the production and transformation of social reality, as opposed to a reproduction of it (Bang and Wajnerman, 2010, p. 97). Finally, in addition to being transformational for participants, we must consider that art can be strategically political both in its processes and in its content.

In a similar trajectory to community arts we find the field of community media. Community media 'have the power to move community members from being dependent and passive in order to become actively involved in the creation of a more meaningful society'(Paranjape, 2007, p. 468). Local, community media values local cultures and grassroots governance, and it 'both produce[s] and maintain $[\mathrm{s}]$ the culture of a community' (Forde et al., 2002, p. 
57, emphasis in the original). Same as in social movements and community arts, in community media practice we often find leaders, change makers, or 'media activists' who act as facilitators for collective practice with the aim of aiding community development (Paranjape, 2007, p. 462).

Within the broad range of practices that encompass community arts and media, a widespread genre is that of community murals. Community mural art is often associated with the renewal of urban spaces, but also with renewal in a broader social sense. Community mural movements tend to emerge during times of social, economic or political unrest, as was the case of the murals in Belfast during The Troubles (Lisle, 2006), and bring with them a desire for change (Marschall, 2002, p. 48). Murals can be tools and signs of revolution, but can also serve to sustain a movement internally. Reed explains how Chicano murals in the US went from earlier revolutionary artworks to pieces designed to promote pride against daily racism, and fight against intra-community violence (2005, p. 115). These motivations overlapped in turn with the function of murals in struggles over public space. Murals, adds Reed, are often collectively produced, making the process of production in itself participatory, and a space for collective identity building and political action (Ibid, p. 116).

Another example of such practices is the 'open radio'. A widespread form of movement building in Argentina, open radios are gatherings, usually taking place in a public space such as a square, during which a group of people host conversations, play live and/or recorded music, and make speeches. The radio can either be live broadcasted, or remain as an unrecorded, site-specific event. The open radio, argues Argote (2013), serves as a tool for communication, public visibility, and social relations. It takes a form-the radio-that is familiar to all, and repurposes it as a political tool in the public space. Open radios are linked to a tradition of community radio, a widespread medium for community development across the world. Community radio offers a space for people to talk about local concerns. It facilitates empowerment and the consolidation of communities. The local nature of these radios can play a crucial cultural role by 'enabling dialogue between diverse components of a community, building on a common background, shared culture and experience' (Forde et al., 2002, p. 56). Community development begins with talking about the issues that confront a community and how to address them (Gaynor and O'Brien, 2012, p. 437). Adopting an event modality within the medium of radio, open radios act as public events where these conversations can take place.

Another widespread form of community expression is the festival. Community festivals can be rooted in the local identity of the place where they are held (Scheper and Dalla Déa, 2012, p. 9), or be organised by communities with other kinds of shared identity, such as Latin American festivals, or groups organising around a particular issue like the fight against sexual assault (e.g. Li, 2018). In the same way as open radios, festivals bring together communities to one location, and as such can act as facilitators of other social processes such as political community organising. While festivals are not always politically oriented, they can be important spaces for counterculture and political action, a tradition that goes back decades (McKay, 1996).

Collaborative and participatory creative practices mobilise certain 'forms of intersubjective affect, identification, and agency' (Kester, 2011, p. 68). Kester argues that in cases of collaborative and participatory art practice, 'the act of expression is generative and contingent. Rather than transmitting pre-existing content, expression takes place through an unfolding, extemporaneous process among an ensemble of collaborative agents.' (Ibid, p. 114). He frames these kinds of practices as dialogical (Kester, 2004), meaning that they involve the co-presence of bodies in real time', and 'revolve around an experience of reciprocal modelling, as each subject shifts roles, anticipates, mirrors, and challenges the other' (Kester, 2011, p. 114). In other words, when considering these forms of art and media and their potential for generating dialogical spaces, we are considering the capacity of media as 'vectors of affect' (Cefai, 2018).

\section{METHODOLOGY}

This study draws from a variety of qualitative data and focuses specifically on the way in which community arts and media have become crucial mediators in collective identity processes in Vista Alegre's fight against fracking. In the first place, I engaged in participant observation in Vista Alegre for three consecutive days in August 2017. The visit was part of a ten-day trip to the province of Neuquén, Patagonia, during which I engaged in participant observation and informal conversations and conducted six other in-depth interviews with environmental activists in other parts of the province. The trip to Vista Alegre was timed in order to coincide with the open radio event, and it included active participation in the open radio, informal conversations and joint meals with several community members, short trips to neighbouring localities and one semi-structured in-depth interview with Milton, a community leader. The interview with Milton was crucial to the study because of his elemental role in both the campaign against fracking and in the running of Vista Alegre's main cultural hub, 'El Remanso'. After hearing about the case of Vista Alegre through other interviewees months earlier and having spoken to Milton informally, I travelled there with the aim of studying a particular aspect of Vista Alegre's movement against fracking: the role of community arts and media. Having a concrete research question, this type of short-term 
ethnographic approach was elected as a suitable research method (Van Maanen, 1988). The data gathered included audio recording, photographic records and fieldnotes.

In the second place, I conducted text analysis of the Facebook page for Vista Alegre Libre de Fracking y en Defensa de la Vida (Vista Alegre Fracking-Free and in Defence of Life) since its creation in May 2016 up to January 2018. This involved the analysis of both images and text about the campaign and the events and actions organised by the assembly, as well as posts sharing external content such as mainstream and alternative media articles. Finally, images of artwork and events taken during participant observation were also analysed, acknowledging the specific value of images in ethnographic research (Pink, 2001).

My approach involved methodological triangulation in order to present a nuanced analysis of the ways in which community art and media are being employed in collective action. Because the conflict in Vista Alegre is ongoing, this article does not aim to provide a closed analysis of the beginning, development and resolution of a conflict, or trace the evolution of collective identity. Rather, it looks at how community art and media are being instrumentalised in a context of socioenvironmental conflict of local and global dimensions, and aims to suggest a frame for understanding the role of community art and media as mediators in collective identity processes, and as vehicles for cultural resistance at the micro level.

\section{THE THREAT OF FRACKING}

Vista Alegre is a municipality in the province of Neuquén, Argentina, located $24 \mathrm{~km}$ north of the provincial capital. It is situated in a region traditionally known for its fruticulture economy, and although not part of recognised indigenous mapuche territory, the majority of Vista Alegre's close to 4,000 inhabitants identify as being of mapuche ancestry ${ }^{2}$. In early 2016, inhabitants from Vista Alegre became aware of the government's intention to enable fracking in their locality. Oil extraction had for long been a major source of income in nearby parts of the province, and fracking, a non-conventional form of fossil fuel extraction, had begun to take place in recent years, following the discovery of the Vaca Muerta (Dead Cow) shale play, one of the largest reserves of nonconventional fossil fuels in the world (Taller Ecologista and Observatorio Petrolero Sur in EJES, 2018) ${ }^{3}$. In response to this development, members of the community began to carry out research on fracking and the potential risks associated with this technique, and consequently mobilised to try to ban fracking in the immediate area and nearby river banks ${ }^{4}$. They organised road blockades and handed out informational leaflets; they put together a report on the negative impacts of fracking collecting information from previous cases in Latin America and beyond; and they worked towards placing the issue in the media. That same year a number of community members decided to create an assembly, which they called Vista Alegre Libre de Fracking y en Defensa de la Vida (Vista Alegre Fracking-Free and in Defence of Life). They also began to generate alliances with other groups and sectors of society opposing fracking, such as the indigenous organisation Confederación Mapuche de Neuquén (a coalition of mapuche communities at provincial level), and the NGO Observatorio Petrolero Sur, a research organisation and oil industry watchdog. After a year of hearing rumours about the arrival of fracking followed by months of gathering information and over half a year of collective struggle, in December 2016 the community of Vista Alegre managed to submit an ordinance for the banning of fracking in the area during an extraordinary session of the local council. This was signed and approved unanimously and to the surprise of the provincial government, only to be declared unconstitutional a year later ${ }^{5}$. The conflict is still ongoing.

Vista Alegre has certain elements that define its collective identity as a municipality and community: its closeness to the river, the region's tradition of fruticulture, a way of living defined by the dynamics of small towns in rural areas, and its mapuche heritage. While the inhabitants of Vista Alegre are not part of a mapuche lof or community, elements of the mapuche cosmovision are embedded in their understanding of the environment and their position within it. Furthermore, there has been a recent strengthening and promotion of mapuche cultural heritage in the town, made manifest for instance in the offer of Mapudungun (mapuche language) lessons at the cultural centre. This celebration of mapuche heritage as well as Vista Alegre's collaboration with the Confederación Mapuche de Neuquén can be understood within a political resurgence of indigenous peoples and the formal establishment of

\footnotetext{
2 While there is no statistical data for this, participants have told me around $80 \%$ of the town's population identifies as having mapuche heritage.

${ }^{3}$ The exploitation of non-conventional fossil fuels in the area had begun to be championed by the centre-left administration of Cristina Fernández de Kirchner in the last decade, and continues to be a strategic activity for the right-wing government of Mauricio Macri, elected in late 2015.

${ }^{4}$ At the time the Argentinian state oil company YPF (with Petrobras and Pampa) had already drilled some conventional wells in the area, and the company Pan American Energy was operating the gas field Lindero Atraversado, also in the adjacent area. For more information see the following report by Platform (2017) 'Argentinian community defies BP and Petrobras to ban fracking' https://platformlondon.org/2017/04/03/vista-alegre-fracking-argentina/

${ }^{5}$ See (in Spanish) Loncopan Berti, Laura (2017) 'Vista Alegre se quedó sin su ordenanza antifracking'. Río Negro.

http://www.rionegro.com.ar/region/declaran-inconstitucional-una-ordenanza-antifracking-ED4162798
} 
their collective rights, which in Argentina and other countries in the region began in the 1990s. It must also be considered in relation to a history of devastating environmental, economic and social effects of conventional fossil fuel extraction in and around mapuche territory in the region, which also goes back decades (Pérez Roig, 2014, p. 160).

The neighbourhood of Costa de Reyes, one of the four neighbourhoods making up Vista Alegre, had also been particularly marked by a recent period of gang-related violence among young people in the early 2000s, which led to the death of a young man. The people of Costa de Reyes took this as a turning point and decided to take action to improve the lives of their young people. They realised murga, a form of combined arts performance genre from the banks of the Río de la Plata in Argentina and Uruguay, could function as an activity that combined many different art forms, from painting to poetry, dance and percussion, and that it could also generate a space for politics, meaning it could be a space for building an understanding and critique of society. Led by Milton, a local community leader, in the year 2000 they began the murga Sueños Compartidos (Shared Dreams), and became a referent group for the other neighbourhoods in the district as well. Murga, says Milton, has an important element of critique, but it can also be about proposing alternatives. He adds: "With the murga for instance we criticised the educational system, so we then decided to generate a library where we could offer courses to children in the neighbourhood." 6

The arrival of fracking as a new, external threat, led to a number of changes that had an impact on the community of Vista Alegre. In the first place, the neighbourhood went from dealing with internal conflictsustaining the cultural provision for the youth in order to avoid a return to violence and rivalry - to dealing with an external threat. Second, they went from having a lifestyle that is in itself alternative to advanced capitalism, to being part of a protest movement against extractive capitalism and imperialism, together with other organisations on a local and transnational level. These two transformations took place under the threat of the most brutal of changes: the pollution of the rivers Neuquén and Negro, and the shift in the region from an agricultural economy to a fossil fuel one, with all the social, economic, and environmental changes that would entail.

\section{BUILDING AN OPPOSITION}

Milton López is a mover and shaker in the Vista Alegre community. He runs the local cultural centre El Remanso (the only cultural centre in the municipality), and has been at the forefront of the fight against fracking since 2016. I first met Milton in person in August 2017 when I visited the Costa de Reyes neighbourhood, which is the active centre of the fight against fracking. He told me about how the community had been organising since the previous year, talking to other members of the community, going on marches, attending meetings to learn more about the topic, and gathering whatever little money they could to sustain the struggle. Milton describes the threat of fracking entering their community in the following way:

We believe that this is aiming towards the dispossession of communities and their ability to continue to live almost independently from the capitalist system. Because here you have some land, and you have good water, you can keep your own animals. But when you break apart the ranches, when pollution starts, and when the production zones begin to be dismantled for the construction of housing for those working in the fossil fuel industry, all of this generates inequality $[\ldots]$ We live in a privileged place, and we think this is what bothers the state. That with so little money we can be as happy as we are, that we can live so well.

Contrary to the personal transformations manifested in the up taking of ecological values or 'greening of the self undertaken by subjects as a result of environmentalism in the Global North, in countries like Argentina environmental conflicts often involve 'a broad array of actors seeking to defend local livelihoods and wellbeing' (Merlinsky and Latta, 2012, pp. 191-2). Furthermore, 'popular actors increasingly seek to participate in the construction of environmental problems in reference to dominant scientific and technological cognitive frames' (Merlinsky and Latta, 2012, p. 192). The narrative against fracking espoused by Milton and the assembly in Vista Alegre is not one that focuses specifically on environmental, land, economic, or health issues, but rather adopts a holistic perspective. What is at stake is a way of life. An extract from the Facebook page description of Vista Alegre Libre de Fracking, which was initially created with the aim of organising the local community but now has gathered hundreds of external followers, states the following:

It is important that the whole community joins this claim, this struggle that is just beginning. When the years go by, we want to still be able to enjoy the river with our family, our children, and future

\footnotetext{
${ }^{6}$ Milton López, personal interview, 26 August 2017. Translation from Spanish by the author.
} 
generations. This is only the beginning, it doesn't matter which culture or ideology represents us, because if we do not act fast the consequences of pollution will drag us all down with them ${ }^{7}$.

The above statements put forward three main points: First that the struggle is for common goods (specifically, the river), and second, that the damaging or disappearance of the commons would destroy a whole way of life. These statements manifest the inherent tension between the ideology and practices of extraction and that of the commons (Dahlin and Fredriksson, 2017, p. 254), also questioning the productivist criteria with which Western rationality evaluates the sustainability of territories (GER-GEMSAL, 2013, p. 767). But the struggle is not only a material one, it is also a symbolic one (Dahlin and Fredriksson, 2017, p. 268), as the understanding of water and land in Vista Alegre does not fit into the extractivist logic of resource. The third point, made in the Facebook page statement, is that everyone is at risk, and everyone should therefore be part of the mobilisation against fracking. Getting the whole community behind this cause is something Milton has been working on since the beginning of the conflict. As the man behind El Remanso, he has used his position to facilitate the sharing of information and encourage community members to join the fight through the use of community arts and media, as I will expand on later.

The assembly is aware of the way in which their localised struggle is also connected with other movements at a global scale, as is often the case in movements resisting fracking (Stasik, 2017). In our conversations, members of Vista Alegre's assembly made reference to other movements against fracking they have established contact with, such as those in the United States. Also, the assembly often shares information about fracking in other countries through their Facebook page. Mobilisations against fracking can be described as 'place-based yet engaging with transnational networks' (Escobar, 2004, p. 221). This gives place to the building of a narrative that draws from preexistent struggles against fracking in other parts of the globe; that adheres to an anti-imperialist stance that is widespread in the Latin American region, but that is still also centred around 'place-based epistemologies, economies and ecologies' (Escobar, 2004, 2008). In other words, it not only attempts to preserve the characteristics of the locality, but also upholds the relationship between the local community and the land as a legitimate source of knowledge and as a relationship under threat to be preserved.

\section{THE ROLE OF THE ARTS AND MEDIA IN THE FIGHT AGAINST FRACKING}

From the success of the murga project and the need and want to generate more cultural activities for both young and old members of the community, came El Remanso, Vista Alegre's cultural centre situated in the neighbourhood of Costa de Reyes. The centre is open to anyone who wants to share a particular knowledge or skill. It has a closed activities room and an open-air stage in the back garden, which was collectively built by a group of neighbours. Milton explained how that stage has been a platform for much of their communications activities in the fight against fracking. It allows them to host bands or shows, and allows the rest of the local community to come along and hear about the struggle. This way, he said, people slowly begin to understand what's going on.

From the belly of El Remanso came a number of activities aimed at building a collective fight against fracking. In March 2017 El Remanso held a festival called Art Festival in Defence of the Rivers. The festival was held outdoors, and it featured photography and painting exhibitions by local artists, live music, games, sharing of food, and sharing of information about the current issues affecting the two main rivers in the Neuquén province. From the Facebook page of El Remanso, and later shared in the assembly's page, read the words:

Last Saturday we shared a day of pure magic, of art, of small big rites that filled us with strength. With certainty and reaffirming that we are on the right path: the path of collective struggle, of a struggle that includes the arts, with the same loved ones as always and with others yet to meet.

The reason people came and listened, according to Milton, is that El Remanso had already been able to demonstrate a consistently strong work ethic through previous projects, such as the murga. In other words, Milton argues that the tangible impact that the work of El Remanso has had on the social fabric of the neighbourhood is why people also attend cultural events related to fracking. This trust is evidenced by the fact that the centre survives only on support from the local community, as confirmed by other community members I encountered on my trip. It was also corroborated by my observations of the planning and delivery of the open radio, which will be described shortly.

Another visual arts initiative that emerged from El Remanso in the context of resistance to fracking was the painting of murals in Costa de Reyes. Led by a local artist and art teacher, young people from the area took part in the design and making of four murals situated at the entrance of the neighbourhood in November 2016. One of

\footnotetext{
${ }^{7}$ This statement features as the page description for the assembly's public Facebook page. Translation from Spanish by the author.
} 


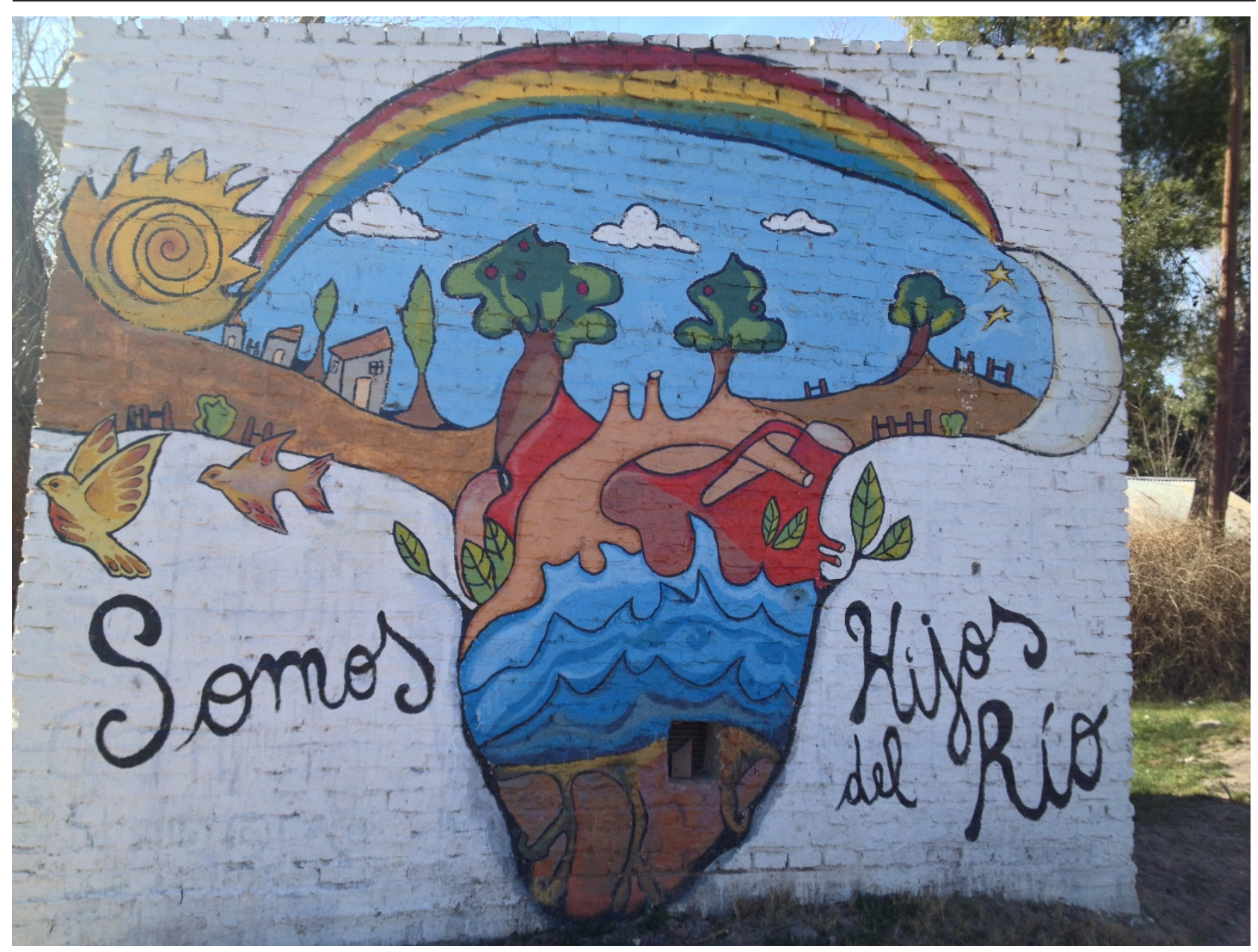

Figure 1. Mural reading 'We are children of the river'. Photograph by the author

the murals presents the image of the land, a blue sky and the river morphing with the figure of a womb, and surrounded by the sun, the moon, and birds. The mural also reads the phrase 'we are the children of the river' (Figure 1). The second one is an image of cultural centre El Remanso next to the river, also featuring musical instruments and an image of a shining sun. A third mural states 'Welcome to Costa de Reyes, land where dreams are shared', and shows a man picking red apples from a tree, a symbol of the local fruticulture economy (Figure 2). And the fourth mural shows the image of an indigenous woman with black breaded hair making bread, and surrounded by flora.

All four murals allude to elements of Vista Alegre's place-based identity. Some of the pieces also make reference to the cultural activities of the neighbourhood specifically: the description of Costa de Reyes as a land where dreams are shared refers to the murga Sueños Compartidos, and the image of El Remanso celebrates the activities of the local cultural centre. Finally, several elements represented in the murals such as the symbiotic relationship to the river, the traditional local economy, and the indigenous heritage, which are central to Vista Alegre's placebased identity, have also been placed at the centre of local narratives against fracking. In addition to the aforementioned murals, in 2018 the assembly organised further mural-painting events, which they called muraladas, and which featured visiting artists from outside the area. Mural-painting is conceived of here as an event-based and process-centred community art form that engages local youth, and also, as an output that becomes a longstanding in situ communication piece.

The third medium that people in Vista Alegre have employed in the fight against fracking is the open radio. The Costa de Reyes neighbourhood was host to an open radio on 26 August 2017, which I attended during my visit. The event had a slow start in the early afternoon, and went on until the early evening. Around 3:00pm a sound system was set up in a local square, and a DJ started playing music. People began to arrive slowly, encouraged by Milton who regularly interrupted the music to invite the local community into the square, and let them know we were going to have an afternoon of games, music, community, and updates on the fight against fracking. Overall around 100 people attended the event, many of whom were children, and joined the games Milton had prepared. There were also two bands playing. The first, Sequía, played folk music with political messages. In-between songs they explained the poetic and political meanings of their songs and expressed their opposition to fracking, and they also addressed the crowd in Mapudungun, the mapuche language. The second band that played towards the end 


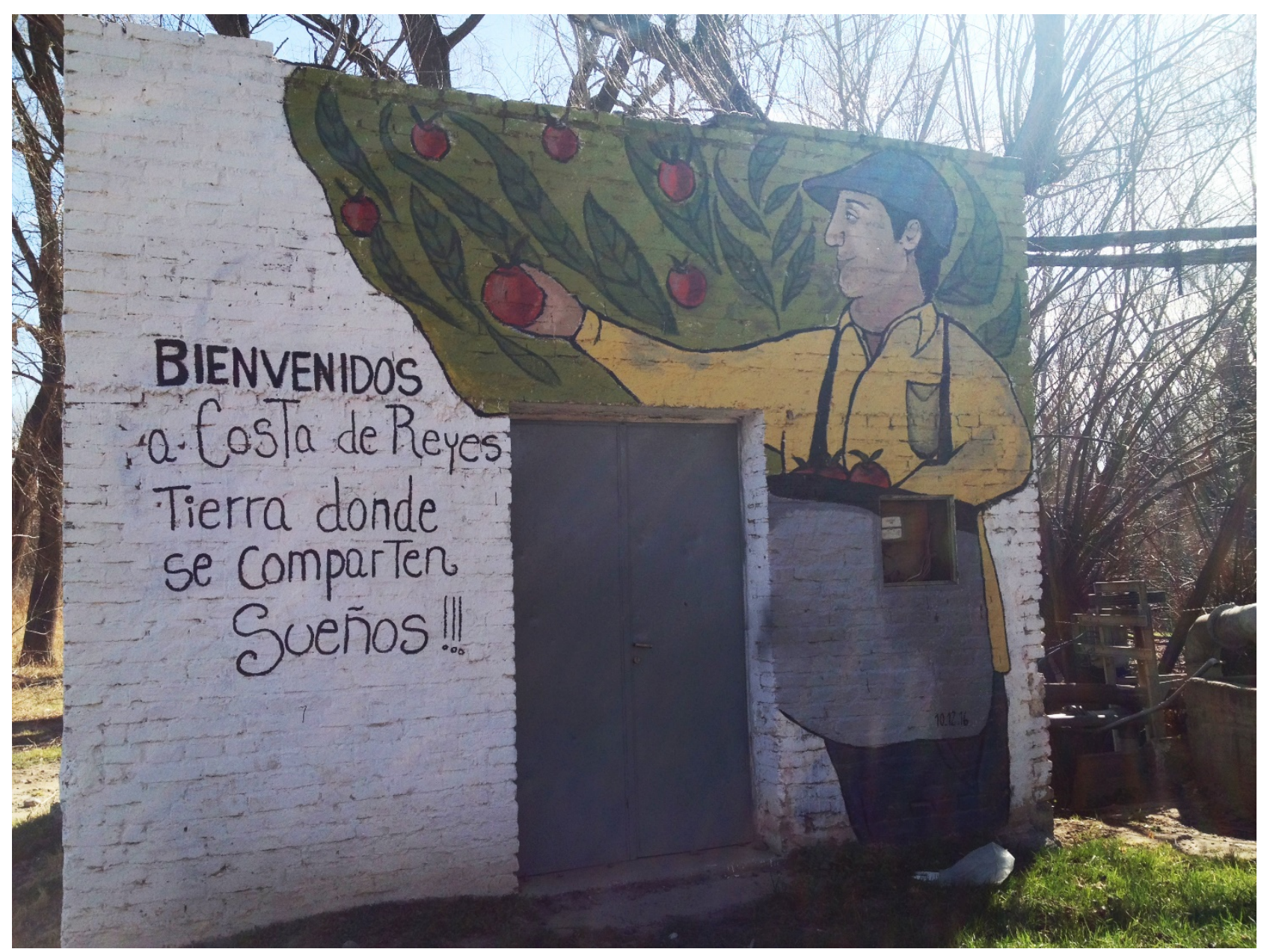

Figure 2. Mural reading 'Welcome to Costa de Reyes, land where dreams are shared'. Photograph by the author

of the event was a local band. They played chamamé (an upbeat Argentine folk genre), and the event came to a close with dancing.

Another important aspect of the event was food. We made torta frita (a pastry made out of flour, water, and lard) on the side of the square, and prepared hot chocolate. In a humorous tone, Milton said on the microphone 'let the water be for torta frita and mates, not for fracking!'. Throughout the event Milton provided a few brief updates on the ordinance the assembly had presented in order to ban fracking in the municipality. As a guest from the UK, I was also invited to say a few words about the fight against fracking in my country of residence, contributing to reinforcing the global level of the struggle. Overall the event was as much of a community-building exercise as it was an event for sharing information. A limited amount of updates on the legal status of the ordinance were provided through the microphone, and updates were also shared with people on a one-on-one basis as they arrived in the square.

\section{TACTICS FOR THE MEDIATION OF COLLECTIVE IDENTITY}

Considering the examples discussed and the perspectives offered in the reviewed literature, I was able to identify three main, overlapping tactics that characterise the way in which arts and media practices are being instrumentalised in the fight against fracking in Vista Alegre with the aim of consolidating collective identity and as a result, strengthening collective action. These are participation, knowledge sharing and the event modality. By considering these three concepts, we can further understand the ways in which community arts and media can take on a role in collective struggle.

The first tactic is participation. The above events allow instances for participation and the strengthening of social relations, such as joint cooking, dancing, playing music, and presenting creative work. Creative participation gives place to the 'group process' outlined by Bang and Wajnerman (2010), and can lead to feelings of ownership over a project, to sustained involvement and to transformations at the individual and collective level (Kester, 2004; Bang and Wajnerman, 2010). Furthermore, in the context of social movements and activism, creative participation

${ }^{8}$ Mate is an herbal infusion common in several South American countries. 
can be a pathway to political participation (Serafini, 2018b). Participation is an important element of mural painting, as young people are given the opportunity to decide what elements represent them and their neighbourhood and what it is they are fighting for. They are also provided an opportunity to produce the murals themselves, thus becoming active agents in the building and representation of the neighbourhood's collective identity on both a discursive and material level. Events such as festivals also allow participation on multiple levels, from socialising to the opportunity to exhibit work or perform for the community, as several local artists did.

The second tactic is knowledge sharing. During events such as festivals and open radios, knowledge sharing about fracking and the developments in the conflict is carried out in two ways: through general announcements and speeches, and through one-to-one conversations that take place as part of socialising. In mural painting on the other hand, there are two stages of knowledge-sharing: the first is a communal sharing during the production of the mural. This is not restricted to the conflict surrounding fracking, but also involves the sharing of feelings and ideas about the neighbourhood, the river, and the identity of the area. The second involves the sharing of these ideas and feelings with the wider community once the murals are done, and take on their role as agents in the construction and representation of local narratives and a collective identity. Community arts and media are therefore sites where knowledge is both shared (news and technical information) and dialogically generated (local narratives about the conflict).

The third tactic is the event modality. During special, programmed events such as festivals and open radios, community members are drawn together into a particular space at a particular time. But other art forms which are usually not regarded as event-based, such as mural art, can adopt an event modality as well when framed as such by organisers. This was the case for the recent muraladas (mural painting public events) in Vista Alegre, which featured visiting artists. Indeed, the turning of mural painting into an event is common to other socioenvironmental struggles in Argentina, as is the case of the movement against open-pit mining in Andalgalá, province of Catamarca ${ }^{9}$. The event modality dictates a cultural calendar and acts as a way of bringing the community together. It allows specific instances of participation and knowledge sharing (e.g. through one-to-one informal conversations or through amplified, performative announcements) that would not be possible on such scale, for instance, if the chosen media was a community newspaper.

These art and community media forms and the dynamics they allow can be seen as dialogical, as they are collectively built, generate social spaces, and allow horizontal conversations and transformations. Milton and other members of the assembly are taking the creative efforts and communal forms of artmaking that had already been flourishing in the neighbourhood since the creation of El Remanso and the murga, and using these and new practices for generating transformational spaces that can strengthen the local resistance to fracking. Through participation and knowledge sharing in community events, the organisers open up a space for collectively negotiating and then reproducing narratives in defence of the common goods and against fracking. Through this exercise, they facilitate a shift in the community's identity, which is no longer only defined by its traditions, economy and relationship to the land but now is also defined in relation to the external threat of fracking. Finally, these arts and media practices are not only tools in organising but also a way of preserving a lifestyle under threat, and can therefore be seen as symbolic, relational and material forms of cultural resistance.

\section{CONCLUSION}

The threat of fracking has become an object of mobilisation for the community of Vista Alegre. This mobilisation, generated by a group of neighbours that work towards including the whole community, makes manifest Vista Alegre's determination to preserve their local environment and traditional economy, as well as their adherence to regional and international movements against fracking and extractivism more widely. As a result of the external threat of fracking, there has been a re-enforcement of the place-based identity of the community in defence of their land, water, and way of life-slogans like 'let the water be for torta frita and mate, not for fracking' and 'we are the children of the river' capture the assembly's objective of reinforcing the local identity, centring common goods (the river) as the issue at stake, and placing fracking as a threat against a long-standing way of life.

In the fight against fracking, collective identity processes are mediated through the use of such media and platforms as festivals, murals and open radios, all forms of popular, participatory arts and media that act as opportunities for strengthening and sustaining community bonds whilst serving as spaces for sharing information and introducing the anti-fracking agenda into the collective identity of the neighbourhood. Identities are mediated through dialogical, rite-like instances of community arts and media. Mediation here means allowing multiple identities to coexist, evolve, and become engrained, from the long-standing, local, place-based identity to a transformed collective identity that also includes a stance against fracking. More specifically, the tactics of

${ }_{9}^{9}$ Personal interview with Rosa Farias, member of the Asamblea del Algarrobo in Andalgalá, an assembly fighting open-pit mining. 27 February 2018.

$10 / 13$

(C) 2018 by Author/s 
participation, knowledge sharing and the event modality facilitate this process by opening up dialogical spaces. The three tactics combined are particularly well suited to a context of ongoing conflict in which what is needed is mass community involvement, opportunities for learning and sharing relevant information, and opportunities for generating and strengthening feelings of ownership over the cause. As with all participatory practices, however, the extent to which participation results in active political engagement for all has limits, as the uneven involvement of actors in organising and decision-making can result in different levels of agency within the collective (Serafini 2018b, pp. 59-60).

We can also consider these forms of community arts and media as 'productive' outcomes of the conflict, meaning mid-term transformations in social life that are generated by such conflict. This implies moving away from a 'win or lose' perspective on movements, and towards an understanding of conflicts as 'horizons for the reconfiguration of social relations' (Merlinsky, 2015, p. 10). In the case of Vista Alegre, it is particularly useful to highlight the productivity of these creative forms of identity building and resistance instead of focusing only on the legal outcomes of the mobilisation in order to understand its social effects, given the limitations of legal remedies to socioenvironmental conflicts. In Argentina, there is still 'a significant gap between the formal recognition of rights and their implementation in substantive practice' (Merlinsky and Latta, 2012, p. 195). The opposition to fracking has led to consolidating a growing programme of creative community activities that differentiate the neighbourhood and its particular struggle as one embedded in arts and participation. Art and media have become significant products of the conflict in generating symbolic, relational and material forms of cultural resistance, understanding cultural resistance as 'culture that is used [...] to resist and/or change the dominant political, economic, and/or social structure'(Duncombe, 2002, p. 5).

Symbolic resistance is found at the narrative level, in the way the opposition to fracking is framed and narrated, be these through slogans stated out loud during events, or through the visual narratives that are constructed in murals. Relational resistance is found in the strength of the community bonds, enhanced and sustained through community arts and media. And material resistance is found in the ways in which the physical spaces of Vista Alegre are transformed as a result of these practices, become sites of rite, communication and place-based identity building through physical gatherings in squares, and most importantly, through the production of new murals that reconfigure the symbolic as well as the material and aesthetic characteristics of the neighbourhood. This transformed sense of space and relationship to the territory that has resulted from the conflict and from the culture of resistance in Vista Alegre can be understood as a form of 'territorial productivity' (Merlinsky, 2015, p. 11).

While locally the fight against fracking has gained visibility and it can also be linked to a global environmental movement, the national context still remains one of media invisibilisation of environmental conflicts, and the collusion of state and corporate powers results in what has been described as 'David vs Goliath' scenario (Svampa and Viale 2014). Under these circumstances, cultural resistance is especially important because it can facilitate urgently needed shifts in collective understandings of environment, development, and the consequences of the expansion of extractive activities at a regional and national level. Indeed, at the global scale, cultural texts have been crucial in facilitating such shifts with regards to fracking, as has been the case of the documentary Gasland (Vasi et al., 2015).

This paper has contributed to the fields of media studies and social movement studies by providing a qualitative account of one of the most pressing socioenvironmental conflicts in Argentina at the time of writing: the expansion of fracking. Most importantly, it makes a theoretical contribution in developing the concept of mediated identities in the specific context of community and place-based collective action. To this end, a framework for understanding the tactics through which community arts and media mediate collective identity processes was offered. Further work in this area could apply or adapt this framework to other contexts, in order to gain a comparative understanding of how different media play a part in the formation and transformation of collective identity at the micro level).

\section{ACKNOWLEDGEMENTS}

This project was made possible thanks to the support of The British Academy/Leverhulme Trust. I am grateful to the community of Vista Alegre, and to all the activists, educators, artists and defenders of the land who took part in this project. 


\section{REFERENCES}

Argote, R. V. (2013). Radio abierta: aproximación teórica sobre la práctica radial en el espacio público. Jujuy: Editorial Universidad Nacional de Jujuy.

Bang, C. and Wajnerman, C. (2010). Arte y transformación social: La importancia de la creación colectiva en intervenciones comunitarias. Revista Argentina de Psicología, 48, 89-103.

Cefai, S. (2018). Introduction: mediating affect, Cultural Studies, 32(1), 1-17. https://doi.org/10.1080/09502386.2017.1394339

Colombres, A. (2004). Mitos, ritos y fetiches. Desmitificaciones y resignificaciones para una teoría de la cultura y el arte de América, in J. Acha, A. Colombres and T. Escobar (Eds.) Hacia una Teoría Americana del Arte (pp. 185192). Buenos Aires: Editorial del Sol.

Della Porta, D. and Diani, M. (2007). Social Movements: An Introduction (second edition). Oxford: Blackwell Publishing.

Dewey, J. (1985 [1927]). The Public and Its Problems. Athens, OH: Swallow.

Dewey, J. (2005 [1934]). Art as Experience. New York: Perigee.

Drury, J., Reicher, S. and Stott, C. (2003). Transforming the boundaries of collective identity: from the 'local' antiroad campaign to 'global' resistance? Social Movement Studies, 2(2), 191-212. https://doi.org/10.1080/1474283032000139779

Duncombe, S. (2002). Introduction, in S. Ducombe (ed), Cultural Resistance Reader (pp. 1-16). London and New York: Verso.

Escobar, T. (2004). El Arte Fuera de Sí. Asunción: CAV/Museo del Barro and FONDEC.

Escobar, A. (2004). Beyond the Third World: Imperial Globality, Global Coloniality and Anti-Globalisation. Third World Quarterly, 25(1), 207-230. https:// doi.org/10.1080/0143659042000185417

Gaynor, N. and O'Brien, A. (2012). Because it all begins with talk: community radio as a vital element in community development. Community Development Journal, 47(3), 436-447. https://doi.org/10.1093/cdj/bsr058

Gerbaudo, P. (2012). Tweets and the Streets: Social Media and Contemporary Activism. London and New York: Pluto.

Gerbaudo, P. and Treré, E. (2015). In search of the 'we' of social media activism: introduction to the special issue on social media and protest identities. Information, Communication \& Society, 18(8), 865-871. https://doi.org/10.1080/1369118X.2015.1043319

GER-GEMSAL. (2013). Bienes comunes en la hegemonía extractivista. Disputas y resistencias. In Giarraca, N. and Teubal, M. (eds.), Actividades extractivas en expansión. ¿Reprimarización de la economía argentina? (pp. 413-422) Buenos Aires: Antropofagia.

Fornäs, J. and Xinaris, C. (2013). Mediated Identity Formation. Javnost - The Public, 20(2), 11-25, https://doi.org/10.1080/13183222.2013.11009112

Kester, G. H. (2004). Conversation Pieces: Community and Communication in Modern Art. Berkeley: University of California Press.

Kester, G. H. (2011). The One and the Many: Contemporary Collaborative Art in a Global Context. Durham, N.C.: Duke University Press. https://doi.org/10.1215/9780822394037

Klandermans, B. (1992). The Social Construction of Protest and Multiorganizational Fields. In A. D. Morris and C. M. Mueller (eds.), Frontiers in Social Movement Theory (pp. 77-103). New Haven, CT: Yale University Press.

Klandermans, B., Sabucedo, J. M., Rodriguez, M. and de Weerd, M. (2002). Identity Processes in Collective Action Participation: Farmers' Identity and Farmers' Protest in the Netherlands and Spain. Political Psychology, 23(2), 235-251. https://doi.org/10.1111/0162-895X.00280

Li, W. M. (2018). Art, Activism and Addressing Sexual Assault in the UK: A Case Study, in P. Serafini, J. Holtaway and A. Cossu (eds.), artWORK: Art, Labour and Activism (pp 45-64). London and New York: Rowman \& Littlefield International.

Lisle, D. (2006). Local Symbols, Global Networks: Rereading the Murals of Belfast. Alternatives: Global, Local, Political, 31(1), 27-52. https://doi.org/10.1177/030437540603100102

Martinez-Alier, J., Temper, L., Del Bene, D. and Scheidel, A. (2016). Is there a global environmental justice movement? The Journal of Peasant Studies 43(3), 731-755. https:// doi.org/10.1080/03066150.2016.1141198

McKay, G. (1996). Senseless Acts of Beauty: Cultures of Resistance since the Sixties. London: Verso.

Melucci, A. (1996). Challenging Codes: Collective Action in the Information Age. Cambridge: Cambridge University Press. https://doi.org/10.1017/CBO9780511520891

Merlinsky, M. G. (2015). Los Conflictos Ambientales y el Debate Público sobre el Desarrollo en Argentina. Ciencia e Investigación, 65(3), 5-17.

Merlinsky, M. G. and Latta, A. (2012). Environmental Collective Action, Justice and Institutional Change in Argentina, in A. Latta and H. Wittman (eds.). Environment and Citizenship in Latin America: Natures, Subjects and Struggles (pp. 190-208). New York: Berghahn Books. 
Paranjape, N. (2007). Community media: local is focal. Oxford University Press and Community Development Journal, 42(4), 459-469. https:/ / doi.org/10.1093/cdj/bsm036

Pérez Roig, D. (2014). Fracturando Argentina. Promoción y resistencias al avance de los "hidrocarburos no convencionales", in C. Composto \& ML Navarro (eds). Territorios en disputa. Despojo capitalista, luchas en defensa de los bienes comunes naturales y alternativas emancipatorias para América Latina (pp. 149-167). México, D. F.: Bajo Tierra Ediciones.

Pink, S. (2001). Doing Visual Ethnography. London: Sage.

Polletta, F. (1998). Contending Stories: Narrative in Social Movements. Qualitative Sociology, 21(4), 419-446. https://doi.org/10.1023/A:1023332410633

Riffo, L. (2017). Fracking and Resistance in the Land of Fire. NACLA Report on the Americas, 49(4), $470-475$. https://doi.org/10.1080/10714839.2017.1409376

Serafini, P. (2018). Changing the Narrative: Highlighting Workers' Rights in Environmental Art Activism, in P. Serafini; J. Holtaway and A. Cossu (eds.). artWORK: Art, Labour and Activism (pp. 105-126). London: Rowman and Littlefield International.

Serafini, P. (2018b). Performance Action: The Politics of Art Activism. London and New York: Routledge. https://doi.org/10.4324/9781315183596

Shaughnessy, N. (2005). Truth and Lies: Exploring the Ethics of Performance Applications. Research in Drama Education: The Journal of Applied Theatre and Performance, 10(2), $201-212$. https://doi.org/10.1080/13569780500103877

Scheper, H. J. and Dalla Déa, A. (2012). Introduction: Authenticity and Resistance: Latin American Art, Activism, and Performance in the New Global Context. Latin American Perspectives, 39(2), 5-10. https://doi.org/10.1177/0094582X11430051

Stasik, A. (2017). Global controversies in local settings: anti-fracking activism in the era of Web 2.0. Journal of Risk Research. https://doi.org/10.1080/13669877.2017.1313759

Svampa, M. and Viale, E. (2014). Maldesarrollo: La Argentina del Extractivismo y el Despojo. Buenos Aires: Katz.

Taller Ecologista and Observatorio Petrolero Sur in EJES. (2018). Vaca Muerta Megaproject-A fracking carbon bomb in Patagonia. Available at: http:/ / ejes.org.ar/VacaMuertaMegaproject.pdf

Van Maanen, J. (1988). Tales of the Field: On Writing Ethnography, Chicago: Chicago University Press.

Vasi, I. B., Walker, E. T., Johnson, J. S. and Tan, H. F. (2015). No Fracking Way! Documentary Film, Discursive Opportunity, and Local Opposition against Hydraulic Fracturing in the United States, 2010 to 2013. American Sociological Review, 80(5), 934-959. https://doi.org/10.1177/0003122415598534

Yuen, S. (2018). Contesting middle-class civility: place-based collective identity in Hong Kong's Occupy Mongkok. Social Movement Studies. https:// doi.org/10.1080/14742837.2018.1434501 